\title{
QBD Approach to Predict the in-vivo Performance Based on in-vitro Results using Mucuna pruriens Seed Mucilage as a Novel Tablet Dosage Form Excipient and Dicofenac Sodium as Model drug Candidate
}

\section{Gitanjali Sambhajirao Deokar ${ }^{1, *}$, Harshada Dnyandeo Kakulte ${ }^{1}$, Sanjay Jayprakash Kshirsagar ${ }^{1}$, Dnyaneshwar Ramnath Waghchoure ${ }^{2}$}

1'Department of Quality Assurance, MET's Institute of Pharmacy, Bhujbal Knowledge City, Adgaon, Nashik, Savitribai Phule Pune University, Pune, Maharashtra, INDIA.

${ }^{2}$ Chairman, Ashwamedh Biotech India Pvt. Ltd., Kopargaon, Maharashtra, INDIA.

\begin{abstract}
Background: Aim of the present study was to put forth certain modifications in Quality by design approach to predict the in-vivo performance of dosage form based on in-vivo performance parameter simulation using in-vitro experimentations. Materials and Methods: One factor design was used with prime focus on impact of Mucuna pruriens seed mucilage as excipient on dosage form functionality and applicability. During product development stage, apart from manufacturing variables other impacting parameters considered were $\mathrm{Gl} \mathrm{pH}$, alterations in body temperature and $\mathrm{Gl}$ motility. Factors considered were simulated $\mathrm{pH}$, Temperature and RPM (Rotations per minutes) variations. Process flow worksheet was developed. QTPP (Quality target product profile) and CQA (Critical Quality Attributes) data was generated. Results: Risk assessment and Ishikawa diagram (Cause and effect analysis) were found to be helpful to generate the results predicting in vivo performance of dosage from. The process capability indices helped for judging product/process performance. The study design could be helpful to analyze the alterations in in-vivo performance based on excipient behavior in simulated conditions tested in-vitro. Conclusion: The present research work has successfully used Quality by design approach to predict the in-vivo performance of Tablet dosage form based on in-vitro data simulation. It can be concluded that study design with more number of simulating variables could be helpful pattern to come up with in-vivo performance predictions.
\end{abstract}

Key words: Mucuna pruriens, Seed polymer, Excipient, ObD perspective, Process capability study, Ishikawa diagram, QTPP, CQA.

\section{INTRODUCTION}

\section{Quality by Design (QbD)}

Quality by design is a system for designing, analyzing and controlling manufacturing through timely measurements (i.e. during processing) of critical quality and performance attributes of new and in-process materials and processes, with the goal of ensuring final product safety. The Principle of $\mathrm{QbD}$ is science and risk based product development, risk assessment, lifecycle approach and method design are explained in the quality guidelines of international conference on harmonization that is $\mathrm{ICH}$ Q8 Pharmaceutical Development, ICH Q9 Quality Risk Management, ICH Q10 Pharmaceutical Quality System, ICH Q11 Development and Manufacture of Drug Substances. Key elements in quality by design are quality target profile, critical quality
Submission Date: 23-12-2020; Revision Date: 25-02-2021; Accepted Date: 02-06-2021

DOI: 10.5530/ijper.55.3.144 Correspondence: Dr. Gitanjali S Deokar Department of Quality Assurance, MET's Institute of Pharmacy, Bhuibal Knowledge City, Adgaon, Nashik-422003, Pune, Maharashtra, INDIA. Phone no: +91 7391910365 Email id: deokargs@gmail. com

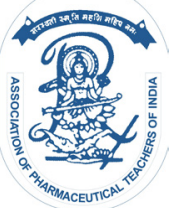

www.ijper.org 
attributes, design space, control strategy and risk assessment. ${ }^{1-3}$

\section{Mucuna pruriens (Velvet beans)}

M. pruriens is a tropical twining herb commonly known as Velvet bean belongs to the family Fabeaceae. $M$. pruriens is very well known for its medicinal utility. In Ayurveda Mucuna pruriens has been well documented for its therapeutic potentials as well as keen interest in phytochemical and Ayurvedic research due to its excellent medicinal values From the ancient times Cowhage has been used in Ayurvedic medicine for the treatment of Parkinson's disease associated with progressive degeneration of dopaminergic neurons in specific areas in the brain which is a common age-related neurodegenerative disorder The beans of the $M$. pruriens are known to produce the unusual non protein amino acid L-dopa, a potent neurotransmitter. it is also used in many other diseases such as for treating arthritis, anxiety, cancer, cough, diarrhoea, dysentery, diabetes, dysmenorrhea, delirium, gonorrhoea, gout, impotence, muscular pain, parasitic infections, rheumatic disorders, as analgesic and antipyretic, to induce vomiting, to treat snakebite (anti-venom activity) and scorpion stings, sexual debility, sterility, tuberculosis and its direct application on skin can help to stimulate surface blood flow in conditions that involve paralysis. ${ }^{4,5}$

Discreet data is available describing the utilization of mucilage isolated from Mucuna seeds as pharmaceutical excipient in dosage for design and development. Numbers of general methods are reported in the literature for the isolation of seed mucilage. ${ }^{6-9}$

The objective of the present research work was to focus on Quality by design perspectives to generate data on the functionality and applicability of dosage form designed using Mucuna pruriens seed polymer as novel tablet dosage form excipient. Predicting the in-vivo behavior of polymer/excipient and ultimately dosage form based on in-vitro simulated testing formed the basis for the present research work.

\section{MATERIALS AND METHODS}

Mucuna pruriens seeds were procured from local market and authentified from western regional centre, Ministry of environment Forestry and climate change, Botanical survey of India, Koregaon Road Pune. Drug used in the study was Diclofenac sodium. All other required chemicals used were of appropriate grades purchased from authentic chemical supplier of the institute.

\section{Methodology}

\section{Isolation of Mucilage component) (Mucuna Seed Mucilage: MSM)}

1. Seeds were grinded in and passed through sieve no. 60. Refer Figure 1 for seeds and seed powder image.

2. Grinded seed powder of 40 gram was weighed and dissolved in a beaker containing $400 \mathrm{ml}$ water.

3. Powder was allowed to soak for $24 \mathrm{hr}$. After $24 \mathrm{hr}$ the soaked powder with water was allowed to boil for half hour and then cooled.

4. Above material was squeezed from muslin cloth and filtrate was collected in beaker. To the filtrate $190 \mathrm{ml}$ of acetone was added and precipitate was obtained.

5. Precipitate was collected in Petri dish and dried in hot air oven at $40^{\circ} \mathrm{C}$. After drying material was collected and ground to obtain isolated component.

6. Obtained mucilage component was stored in desiccators to protect it from moisture which was taken for further characterization study.

\section{Hygroscopicity of Isolated Mucilage}

Excess amount of dried silica powder was placed in the well of desiccator. Samples of each material (100$300 \mathrm{mg}$ ) were weighed $\left(60\right.$ mesh and 100 mesh at $40^{\circ} \mathrm{C}$ and $37^{\circ} \mathrm{C}$ ) in open and tarred glass Petri-plates which then placed into a desiccator which were labelled and maintained at room temperature. After $24 \mathrm{hr}$ of storage, samples were removed from desiccator and final mass of each samples were determined with the aid of calibrated analytical balance.

Formula:

$$
\% \text { increase in mass }=\frac{\mathrm{M} 3-\mathrm{M} 2}{\mathrm{M} 2-\mathrm{M} 1} \times 100
$$

Where, $\mathrm{M}_{1}=$ Mass of empty Petri-plate

$\mathrm{M}_{2}=$ Mass of Petri-plate and sample (Initial)

$\mathrm{M}_{3}=$ Mass of Petri-plate and sample (After $24 \mathrm{hr}$ )

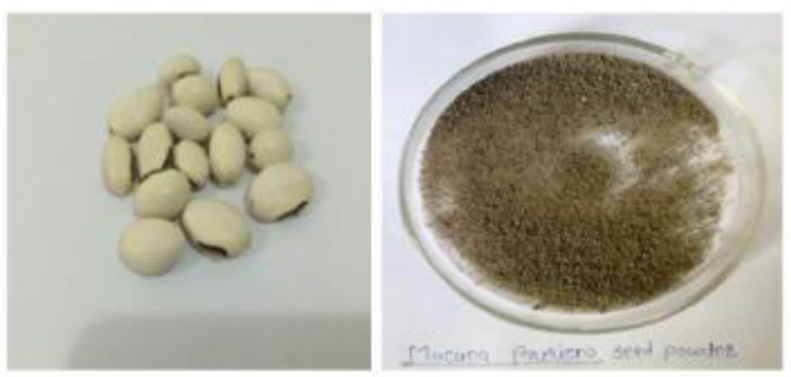

Figure 1: Mucuna pruriens seeds with isolated seed mucilage powder. 


\section{Formulation recommendation and dosage form composition}

Formulation recommendation was performed on the basis of results obtained on pre formulation study carried out on Mucuna Seed Mucilage (MSM) component/ Excipient. All other excipient like talc, magnesium stearate, lactose were selected as per the general tablet formulation composition requirements

\section{Generation of Product development work flow sheet}

During generation of product development work flow sheet both in-vitro and in-vivo parameters responsible for product performance are kept in mind and accordingly QTPP, CQA, Risk assessment, Cause and effect analysis were performed. ${ }^{1}$ During product development only manufacturing variables were not the focus. Other parameters which may have impact on product performance like GI conditions Eg. $\mathrm{pH}$, disease conditions and alterations in physiological parameters, alterations in body temperature, alterations in GI motility were also considered during in-vitro product development process and in-vitro testing. Where ever possible the parameters were simulated during product evaluation steps itself.

Protocol for product development is shown in the form of formulation, development, optimization and validation work flow sheet as shown in Figure 2.

\section{Quality target product profile (QTPP) generation for tablet dosage form (using QbD guidelines)}

QTPP is a prospective summary of the quality characteristics of a drug product that ideally will be achieved to ensure the desired quality, taking into account safety

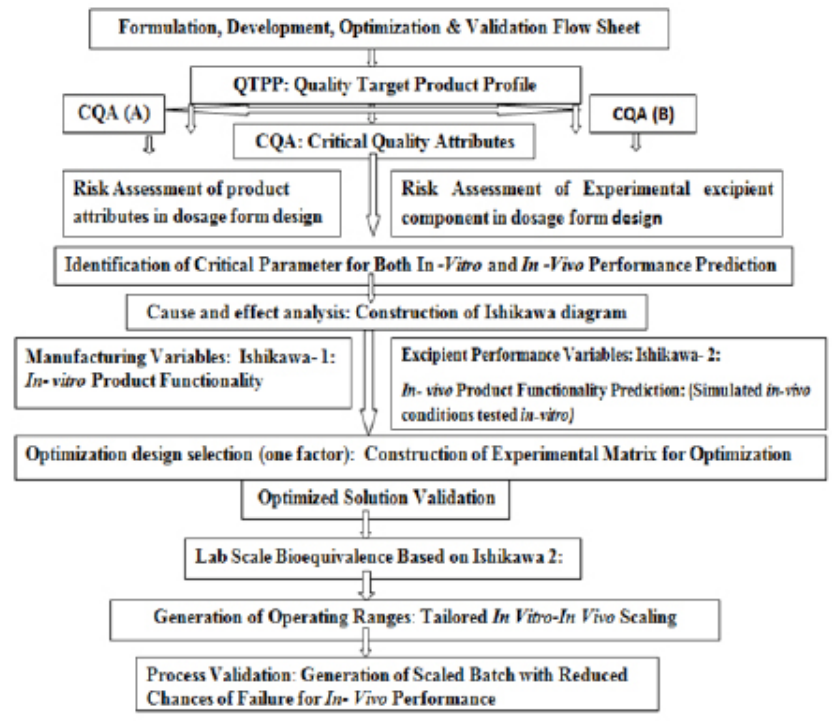

Figure 2: Protocol for Product development (Work Flow Sheet). and efficacy of the drug product. Diclofenac sodium was considered as drug of choice to be incorporated into tablet dosage form with dose of $50 \mathrm{mg}$ which is reported the conventional dose of drug. QTPP were decided as per the pharmaceutical equivalence study requirement, product quality attributes considered were assay, content uniformity and $\%$ release. ${ }^{2,3}$ The generated QTPP as required to generate critical quality attributes is shown in Table 1.

\section{CQA data generation}

CQA is a physical, chemical, biological, or microbiological property or characteristic that should be within an appropriate limit, range, or distribution to ensure the desired product quality. ${ }^{2,3}$ QTPP was considered as a guideline to develop CQAs as mentioned in Table 2.

\section{Risk assessment of Mucuna Seed Mucilage (MSM) Component/Excipient attributes in dosage form design}

The relative risk that polymer component attribute in present work was ranked as high, medium, or low. The same relative risk ranking system was used throughout the pharmaceutical development and is summarized in Table 3 for each risk assessment performed, the rationale for the risk assessment tool selection and the details of the risk identification, analysis and evaluation is also mentioned in the Table 3. The two primary principles that should be considered when implementing quality risk management: The evaluation of the risk to quality

\begin{tabular}{|c|c|c|}
\hline QTPP elements & Target & Justification \\
\hline Dosage form & Tablet & $\begin{array}{l}\text { Pharmaceutical } \\
\text { equivalence } \\
\text { requirement: same } \\
\text { dosage form }\end{array}$ \\
\hline Rout of administration & Oral & $\begin{array}{l}\text { Pharmaceutical } \\
\text { equivalence } \\
\text { requirement: same } \\
\text { rout of administration }\end{array}$ \\
\hline Dosage strength & $50 \mathrm{mg}$ & $\begin{array}{l}\text { Pharmaceutical } \\
\text { equivalence } \\
\text { requirement: same } \\
\text { strength }\end{array}$ \\
\hline $\begin{array}{l}\text { Drug product quality } \\
\text { attributes }\end{array}$ & $\begin{array}{l}\text { Physical attributes } \\
\text { Identification Assay } \\
\text { Content Uniformity } \\
\text { Drug Release etc }\end{array}$ & $\begin{array}{c}\text { Pharmaceutical } \\
\text { equivalence } \\
\text { requirement: Meeting } \\
\text { the Same compendia! } \\
\text { or other applicable } \\
\text { (quality) standards } \\
\text { (i.e., identity, assay, } \\
\text { purity and quality). }\end{array}$ \\
\hline
\end{tabular}


should be based on scientific knowledge and ultimately link to the protection of the patient;

\section{Generation of Ishikawa diagram for dosage form design and product performance in vitro}

Ishikawa Diagram/Fishbone diagram (Cause and effect analysis) is designed taking into consideration both in vitro as well as in-vivo variable responsible for deciding the product performance that is product functionality and applicability.

Ishikawa diagram for product performance prediction both at in-vitro variables and in-vivo simulated variables is highlighted in Figure 3.

\section{Formulation of Tablet Dosage Form}

\section{Optimization design and Experimentation (One factor response design)}

From the Ishikawa diagram constructed in section. Some of the Mucuna Seed Mucilage (MSM) component/ Excipient attributes selected was concentration, temperature to treat excipient sample and particle size. So, one factor design with MSM as quantitative factor and rest of the MSM related parameters were selected as qualitative categorical parameters in the study. The levels of these factors were selected on the basis of initial studies and observations. The data was analyzed using Design expert software.

Mucuna Seed Mucilage (MSM) component/Excipient concentration was selected in the range 50 to $200 \mathrm{mg}$ (with respect to tablet weight of $350 \mathrm{mg}$ ) i.e. \% 14.28 to 57.14 of MSM concentration, particle size of MSM (mesh size of sieve 60 and 100). Temperature for treating MSM was selected $37^{\circ} \mathrm{C}$ and $40^{\circ} \mathrm{C}$. Formulation composition as per one factor design layout, experimental design matrix in actual levels is shown in Table 4 Tablets containing Diclofenac sodium were prepared by wet granulation method using $10 \mathrm{~mm}$ biconvex punch on a tablet compression machine. Data interpretation

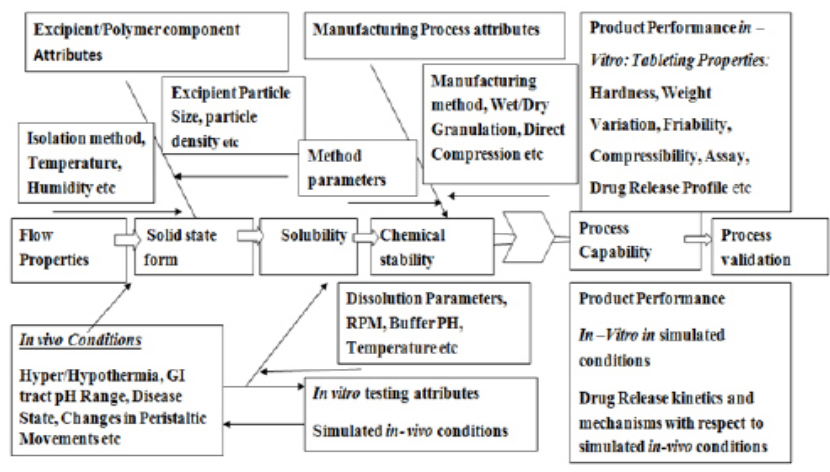

Figure 3: Ishikawa Diagram for product performance prediction both at in-vitro variables and in-vivo simulated variables. and Formulation optimization is done by experimental matrix data analysis and interpretations thereof.

\section{Pre compression characterization of experimental matrix batches}

Characterization of granule blend was carried out by determining bulk density, tapped density, Hausner's ratio, Compressibility index and angle of repose. ${ }^{10}$

\section{Post compression characterization of experimental matrix batches}

Post compression parameters like Tablet thickness, Hardness, Friability, Weight Variation, Uniformity of drug content, ${ }^{10}$ in-vitro drug release study were performed. Study was performed in $1.2 \mathrm{pH} 0.1 \mathrm{~N} \mathrm{HCl}$ for $1^{\text {st }} 2 \mathrm{hr}$ and $6.8 \mathrm{pH}$ phosphate buffer for next study at $50 \mathrm{RPM}$ speed and $37 \pm 0.5^{\circ} \mathrm{C}$ using USP type II dissolution apparatus. Dissolution data was treated for release

\begin{tabular}{|c|c|c|}
\hline \multicolumn{2}{|c|}{$\begin{array}{c}\text { Table 2: Critical Quality Attributes (CQAs) of Tablet } \\
\text { Dosage form. }\end{array}$} \\
$\begin{array}{c}\text { Critical Quality Attributes } \\
\text { (CQAs) of the drug product }\end{array}$ & Target & $\begin{array}{r}\text { Is it CQA? } \\
\text { (YES/No) }\end{array}$ \\
\hline In-vitro Variable & & \\
\hline 1-Physical attributes & Appearance & No \\
\hline & Odor & No \\
\hline
\end{tabular}

\begin{tabular}{|c|c|c|}
\hline \multicolumn{3}{|c|}{ 2-Dosage form Factors/Manufacturing variable } \\
\hline Excipient Particle Size & $\begin{array}{l}\text { Pre compression } \\
\text { parameter }\end{array}$ & Yes \\
\hline Excipient Concentration & $\begin{array}{l}\text { Post compression } \\
\text { parameter }\end{array}$ & Yes \\
\hline Method of Manufacturing & Hardness & Yes \\
\hline $\begin{array}{l}\text { Temperature (may have impact } \\
\text { on Excipient moisture content, } \\
\text { solid state form etc) }\end{array}$ & Thickness & $\begin{array}{l}\text { No (if within } \\
\text { limit) }\end{array}$ \\
\hline & $\%$ drug release & Yes \\
\hline & Content uniformity & Yes \\
\hline & Friability & Yes \\
\hline & Drug content & Yes \\
\hline \multicolumn{3}{|c|}{ In-vivo Variable } \\
\hline $\begin{array}{l}\text { (Performed in-vitro under } \\
\text { simulated conditions) }\end{array}$ & & \\
\hline Gastric Motility changes & Drug Release & Yes \\
\hline $\begin{array}{l}\text { (RPM- in-vitro) } \\
\text { GI pH Variations }\end{array}$ & $\begin{array}{c}\text { (Based on Excipient } \\
\text { behavior and } \mathrm{pH} \\
\text { Partition Hypothesis) }\end{array}$ & Yes \\
\hline \begin{tabular}{|c|} 
(Buffers of varying $\mathrm{pH}$ ) \\
Body Temperature variations \\
(Dissolution study Temperature \\
variations)
\end{tabular} & & Yes \\
\hline
\end{tabular}




\section{Table 3: Justification for Risk assessment of Mucuna Seed Mucilage (MSM) - Excipient component attributes in} dosage form design.

\begin{tabular}{|c|c|}
\hline Excipient Attributes & Justification \\
\hline $\begin{array}{l}\text { Particle size distribution(PSD)/ } \\
\text { Bulk density } \\
\text { CQA's : Physical Attributes, } \\
\text { Assay, Content Uniformity, } \\
\text { Drug release }\end{array}$ & $\begin{array}{l}\text { Particle size and flow properties may have effect on physical attributes like hardness, friability etc. } \\
\text { Flow properties if poor may not give tablets with edge finishing, may not be able to compress etc. } \\
\text { Ultimately, other CQA's may also be affected. MSM sample sieved through } 60 \text { and } 100 \text { mesh could } \\
\text { be used for comparative evaluation and check the effect of particle size on dosage form behavior. } \\
\text { Therefore, the risk of PSD and bulk density to impact the drug product CQA's could be high. }\end{array}$ \\
\hline $\begin{array}{c}\text { Solid state form } \\
\text { CQA's : Physical Attributes, } \\
\text { Assay, Content Uniformity, } \\
\text { Drug release }\end{array}$ & $\begin{array}{l}\text { Solid state form transformation may occur during the compression process with the aid of heat } \\
\text { generation. This transformation may impact drug release. Furthermore, the MSM powder is having } \\
\text { amorphous nature that may get converted into crystalline form during the storage of the finished } \\
\text { product; the drug release profile may change. The risk of solid state form to impact drug release from } \\
\text { the tablets could be high. }\end{array}$ \\
\hline $\begin{array}{c}\text { Hygroscopicity } \\
\text { CQA's : Physical Attributes, } \\
\text { Assay, Content Uniformity, } \\
\text { Drug release. }\end{array}$ & $\begin{array}{l}\text { Because the MSM powder is hygroscopic, the risk of sorbed water to impact tablet physical attributes } \\
\text { (micromeritics), assay, content uniformity (CU) or drug release could be high. }\end{array}$ \\
\hline $\begin{array}{c}\text { Solubility } \\
\text { CQA's : Physical Attributes, } \\
\text { Assay, Content Uniformity, } \\
\text { Drug release }\end{array}$ & $\begin{array}{l}\text { MSM solubility has no impact on tablet physical attributes ( size and splitability), assay, } \\
\text { content uniformity (CU). The risk could be low in dosage form design but risk could be high in } \\
\text { pharmacokinetic and pharmacodynamic dosage form behaviour in the body and therapeutic } \\
\text { response may alter. The MSM powder has moderate dissolution rate and good solubility. It potentially } \\
\text { impact the drug release profile. The risk could be high. Analysis of pH dependent solubility could } \\
\text { help in deciding site targeting of dosage form. pH dependent solubility may show different ionization } \\
\text { potential and different release pattern. }\end{array}$ \\
\hline $\begin{array}{l}\text { Chemical stability } \\
\text { CQA's :Physical Attributes }\end{array}$ & $\begin{array}{c}\text { Stability of MSM has no impact on tablet physical attributes (size and splitability). Assay and content } \\
\text { uniformity (CU) may have high impact with change in stability. }\end{array}$ \\
\hline
\end{tabular}

Table 4: Formulations as per one factor design layout, experimental design matrix in actual levels.

\begin{tabular}{|c|c|c|c|c|c|c|c|c|}
\hline Excipient (mg) & F1 & F2 & F3 & F4 & F5 & F6 & F7 & F8 \\
\hline$(\mathrm{P}, \mathrm{T})$ & (60, & (60, & (60, & (60, & $(100$ & $(100$ & $(100$ & (100, \\
\hline & 37) & 37) & 40) & 40) & 37) & 37) & 40) & 40) \\
\hline $\begin{array}{l}\text { Diclofenac } \\
\text { sodium }\end{array}$ & 50 & 50 & 50 & 50 & 50 & 50 & 50 & 50 \\
\hline MSM (mg) & 50 & 200 & 50 & 200 & 50 & 200 & 50 & 200 \\
\hline Lactose & 235 & 85 & 235 & 85 & 235 & 85 & 235 & 85 \\
\hline Talc $(2.28 \%)$ & 8 & 8 & 8 & 8 & 8 & 8 & 8 & 8 \\
\hline $\begin{array}{l}\text { Magnesium } \\
\text { stearate }(2 \%)\end{array}$ & 7 & 7 & 7 & 7 & 7 & 7 & 7 & 7 \\
\hline $\begin{array}{l}\text { Total weight of tablet } \\
\text { (mg) }\end{array}$ & 350 & 350 & 350 & 350 & 350 & 350 & 350 & 350 \\
\hline
\end{tabular}

Where, $\mathrm{P}=$ particle size of polymer (mesh), $\mathrm{T}=$ Temperature (oC) to treat MSM sample

kinetics and mechanism predictions. Data profiling was done to predict the changes in dosage form performance at the simulated in-vivo condition performed in-vitro.

\section{Experiment matrix data analysis, Optimized solution generation and Validation}

Experimental Matrix data was analyzed and factors having significant impact on the expected response were identified for optimized solution generation. Response surface methodology (RSM) is widely practiced approach in the development and optimization of drug delivery devices.
Based on the principle of design of experiments (DoE), the methodology encompasses the use of various types of experimental designs, generation of polynomial equations and mapping of the response over the experimental domain to determine the optimum formulation. Statistical validity of the polynomials was established on the basis of analysis of variance (ANOVA) provision include in the Design Expert Software. Optimized solution generated was formulated and evaluated for parameters like content uniformity, hardness, thickness, dissolution performance, $\%$ drug release etc. 


\section{Performance Scale up Trials on Optimized Solutions \\ In-vivo biowaiver using in-vitro simulating conditions (RPM, pH, Temperature)}

Optimized solutions generated were further taken for performance scale up trials. Critical parameters/Causes responsible for the expected effects are identified as shown in Figure 2, like acidic $(1.2 \mathrm{pH}, 0.1 \mathrm{~N} \mathrm{HCl})$ and basic (6.8 pH, Phosphate Buffers-PBS) conditions for any change in acidic and basic $\mathrm{pH}$ condition at the site of administration and in turn site of action. RPM conditions like 50 RPM and 100 RPM to represent the change in peristaltic movement of digestive tract. Temperature conditions like $\left(32^{\circ} \mathrm{C}\right.$ and $\left.37^{\circ} \mathrm{C}\right)$ to represent altered temperature conditions of body. One in-vitro parameter considered was change in dissolution media (acidic and basic), paddle and baskets were also taken for comparative scale up trial. Study carried out would help to generate process capability index in terms of behavior in altered body conditions compared to normal physiological conditions. The comparative dissolution data profiling was performed considering the above selected parameters and physiological process performance and process potential was interpreted along with dissolution profiling study.

\section{Dissolution data profiling (Model independent approach-Similarity and dissimilarity factor calculation)}

Optimized formulation was evaluated on the basis of different dissolution conditions for the determination of similarity and dissimilarity factor. The dissolution conditions considered were paddle, basket, $\mathrm{HCl}$ (1.2) $\mathrm{pH}$, PBS $(6.8 \mathrm{pH})$, PBS $(8 \mathrm{pH})$ temperature conditions as $32^{\circ} \mathrm{C}$ and $37^{\circ} \mathrm{C} .{ }^{11,12}$

\section{Generation of process capability indices}

Process capability analysis using normal assumption often leads to erroneous interpretations of the process performance. Profile monitoring is a relatively new set of techniques in quality control that is used in situations where the state of product or process is represented by a function of two or more quality characteristics. ${ }^{13}$ Here normal assumption means we can say conventional pattern of risk analysis like manufacturing process variables. We in the present research work have considered not only the manufacturing process variables but also the in-vivo conditions simulated in-vitro to predict the product performance that is functionality and applicability. Profile monitoring at manufacturing level considering both in-vivo and in-vitro product performance variables can generate very important information which can be helpful to predict results of exhibit batch taken for clinical performance check. A capability index relates engineering specification to the observed behavior of process. The capability of process is defined as the ratio of the distance from the process center to the nearest specification limit divided by measure process variability. ${ }^{14,15}$ Results obtained generates very useful information regarding the dosage form development and dosage form performance.

\section{Risk predictions and Conclusion}

On the basis of data generated from experiment data analysis, process scale up trials, process capability indices, the impact of variables on formulation components were studied on drug product critical quality attributes and high or low risk components were identified for expected response of $\%$ drug release.

\section{RESULTS AND DISCUSSION}

\section{Hygroscopicity of Isolated Mucilage}

Along with other pre-formulation parameter, Hygroscopicity was considered as the important parameter in decision making to consider the mucilage for the study as tablet dosage form excipients. Hygroscopicity values reported for 60 mesh Powder at 40 Degree celcius and 37 degree celcius were $0.98 \pm 1.056$ and $0 \pm 0.022$ respectively and for 100 mesh Powder 40 Degree celcius and 37 degree celcius were $-6.55 \pm 0.056$ and $0.38 \pm 0.0965$ respectively. Hygroscopicity values of 0 to 1.5 ranges indicates that powder could be fruitfully utilized for tablet dosage form design. It shows no impact of environmental humidity which could make it good candidate in dosage form design.

\section{Optimization design and Experimentation (One factor design)}

In order to determine the drug release time profile, Mucuna Seed Mucilage (MSM) component/Excipient was taken as a factor and variation in drug: MSM concentration, particle size of MSM Powder, temperature conditions of MSM Powder were used in order to study the influence of these conditions on the overall drug release and to obtain the optimized formulation by one factor design.

\section{Pre-compression characterization of experimental matrix batches}

The bulk density obtained for all formulations in the range of 0.49 to $0.56(\mathrm{~g} / \mathrm{ml})$ and tapped density in the range of 0.45 to $0.68(\mathrm{~g} / \mathrm{ml})$. Angle of repose of granule blend of all the formulations was found to be in the range of 29.36 to $34.96^{\circ} \mathrm{C}$ which is showing good flow ability, 
necessary for proper flow of granule blend into the die cavity. Carr's index of the granule blend of all formulations was found to be in the range of 7.57 to $16.92 \%$ which indicates the blend would not have any problem during compression of mass between the punch tools, powder mass segregation and mass charge development could be avoided with the obtained care's index value. Hausner's ratio was found to be in the range of 1.09 to 1.20. All these results indicated that, the granule blends possess good compression property and good flow of granule blend into the die cavity.

\section{Post compression parameters}

The tablets were evaluated for hardness, thickness, \% friability and weight variation and content uniformity. The hardness of tablets of all the batches was found in the range 4.10 to $4.55 \mathrm{~kg} / \mathrm{cm}^{2}$. Thickness of all tablets was found to be in the range of 3.121 to $3.186 \mathrm{~mm}$. Tablets showed \% friability in the range of 0.404 to $0.774 \%$ which is within limit. All the formulations pass the weight variation test as per the range limit for weight variation. Whereas Tablets from each batch showed uniformity of drug content in the range of 92.52 to $98.11 \%$ which is within pharmacopoeial specifications. All the formulations complies the test for uniformity of drug content as it was found to be within the limit of 90 to $110 \%$.

\section{In-vitro drug release (Dissolution study)}

As depicted from Table 5 for in-vitro drug release and Table 6 for dissolution mechanism and release profiling, it is seen that concentration of MSM plays very important role in drug release profile.

1. Batches (F1, F3, F5, F7) with $14.28 \%$ concentration could prolong the release of drug for about $12 \mathrm{hrs}$ whereas batches F2,F4,F6,F8 with 57.14\% MSM concentration were about $50 \%$ released at the end of $12^{\text {th }}$ hr could show the release for still more $12 \mathrm{hr}$. The said results focus moreof release retarding behaviour of the MSM Excipient component (Table 5).

2. But the rate of release of drug from all the batches was found to be first order with Maximum $R 2$ values as compared to $R 2$ values of Zero order rate predictions which is also supported by sum of squared error/residual error calculations. The reason could be $\mathrm{pH}$ sentitive solubility and Ionization of MSM excipient component.

3. Release rate prediction of individual batch:

Batch F1: First order which is drug concentration dependent.
Batch F2: Pseudo first order as R2 values of both rate predicting models are close to each other. Pseudo first order prediction as residual error is less with zero order model.

Batch F3: First order which is drug concentration dependent.

Batch F4: First order ( but as values are nearer may be mixed order)

Batch F5: Mixed prediction

Batch F6: Mixed prediction

Batch F7: Mixed prediction

Batch F8: Mixed prediction

4. From the observations for zero order and first order release kinetics predictions, the regression values are very close. So, it can be said that concentration range of MSM may show mixed order pattern of release based on solubility pattern along with other factors like impact of particle size, temperature used to dry the MSM powder etc.

5. Observations among release mechanism predicting models shows the $R 2$ values on higher side (near to 1) for Higuchi model and Korsemeyer peppas with the residual error values lowest for Higuchi release mecahnism

6. From this observation it can be interpreated that drug diffuses out of MSM strucuture chain. But the component might also be showing time dependent solubility/ionization which may lead to erosion of mucilage chain matrix which is ultimatly shifting the release pattern from Higuchi to Korsemayer Peppas.

7. Observations for $\mathrm{N}$ exponent values of Korsemeyer Peppas model indicates that value of $\mathrm{N}$ Exponent for the batches between 0.9 to 1.2 predicts super case II transport for the concentration range selected $(50 \mathrm{mg}$ and $200 \mathrm{mg}$ ) expect batch F3 which is 0.9149 indicates anomalous transport mechanism signifying zero order release which was initially judgemented as pseudo first order release from the regression value for zero order and first order kinetic models.

8. So, the overall conclusion for the observations of readings for dissolution is that concentartion range from 50 to $200 \mathrm{mg}(14.28$ to $57.14 \%)$ is responsible to show anomalous transport mechanism involving diffusion as major mechanism along with time dependent solubility of diffusing polymer chains which ultimately takes the eroding release pattern over the time. Time dependent polymer base release patterns makes the mixed order or pseudoorder kinetics as a major rate of reaction. 
Table 5: In-vitro dissolution data of tablets for formulations F1 to F8.

\begin{tabular}{|c|c|c|c|c|}
\hline \multirow[t]{2}{*}{ Time (hr) } & \multicolumn{3}{|c|}{$\%$ Cumulative drug release } & \multirow[b]{2}{*}{ F4 } \\
\hline & F1 & F2 & F3 & \\
\hline 1 & $4.890416+0.23$ & $3.853652 \pm 0.25$ & $9.302181 \pm 0.21$ & $4.294828 \pm 0.26$ \\
\hline 2 & $6.32935 \pm 0.46$ & $5.838296 \pm 0.56$ & $24.00092 \pm 0.40$ & $10.38486 \pm 0.47$ \\
\hline 3 & $61.61596+0.86$ & $20.33156 \pm 0.73$ & $36.84532 \pm 0.59$ & $19.50587 \pm 0 . .60$ \\
\hline 4 & $66.45827+0.98$ & $23.49956 \pm 0.90$ & $53.93534 \pm 0.76$ & $23.49497 \pm 0.76$ \\
\hline 5 & $69.92192+1.26$ & $25.85884+1.11$ & $69.71549 \pm 0.90$ & $25.85426 \pm 0.93$ \\
\hline 6 & $72.70092+1.39$ & $32.27638+1.34$ & $72.4945+1.16$ & $32.2718+1.19$ \\
\hline 7 & $78.38314+1.69$ & $36.08658+1.60$ & $74.04828+1.20$ & $36.082+1.36$ \\
\hline 8 & $81.20481+1.86$ & $38.43073+1.79$ & $80.97545+1.49$ & $41.2747+71.55$ \\
\hline 9 & $87.13611+1.97$ & $42.06662+1.86$ & $91.0352+1.85$ & $44.14208+1.70$ \\
\hline 10 & $91.73553+2.06$ & $47.9509+2.03$ & $93.18049+1.93$ & $54.6204+1.89$ \\
\hline 11 & $93.88083+2.38$ & $54.81615+2.46$ & $96.16064+2.03$ & $57.14642+2.04$ \\
\hline 12 & $94.59034+2.46$ & $57.17681+2.69$ & $97.91603+2.43$ & $63.27658+2.56$ \\
\hline & F5 & F6 & F7 & F8 \\
\hline 1 & $4.44924 \pm 0.19$ & $3.412475 \pm 0.23$ & $5.463946 \pm 0.20$ & $3.412475 \pm 0.22$ \\
\hline 2 & $15.69749+0.37$ & $4.512316 \pm 0 \ldots 46$ & $18.20018 \pm 0.45$ & $6.409375 \pm 0.52$ \\
\hline 3 & $32.71688+0.53$ & $15.79028 \pm 0.59$ & $32.71688 \pm 0.62$ & $14.96459 \pm 0.73$ \\
\hline 4 & $51.60048+0.86$ & $18.93305 \pm 0.78$ & $56.05919 \pm 0.86$ & $18.10277 \pm 0.88$ \\
\hline 5 & $58.12008+0.95$ & $23.33132 \pm 0.97$ & $61.73659 \pm 0.90$ & $23.32214 \pm 0.98$ \\
\hline 6 & $64.13762+1.09$ & $26.84519+1.08$ & $68.8062+1.00$ & $25.18464+1.13$ \\
\hline 7 & $70.5996+1.38$ & $30.62557+1.23$ & $71.9086+1.63$ & $30.60723+1.56$ \\
\hline 8 & $76.68279+1.53$ & 33. $76559+1.56$ & $79.23715+1.82$ & $36.18302+1.70$ \\
\hline 9 & $86.7196+1.70$ & $37.78909+1.75$ & $81.85653+1.99$ & $39.848+1.88$ \\
\hline 10 & $89.54379+1.92$ & $40.34769+1.97$ & $88.8642+2.18$ & $50.3038+82.14$ \\
\hline 11 & $91.80307+2.00$ & $49.64872+2.11$ & $90.99551+2.56$ & $51.56844+2.25$ \\
\hline 12 & $93.08139+2.56$ & $52.80754+2.43$ & $94.37451+2.86$ & $58.70089+2.65$ \\
\hline
\end{tabular}


Table 6: Dissolution Data modeling for formulations (F1 to F8).

\begin{tabular}{|c|c|c|c|c|c|c|c|c|c|}
\hline Product code & & F1 & F2 & F3 & F4 & F5 & F6 & F7 & F8 \\
\hline \multirow[t]{2}{*}{$(\mathrm{C}, \mathrm{P}, \mathrm{T})$} & & $(50,60$ & $(200,60$ & $(50,60$, & $(200,60$ & $(50,100$ & $(200,10$ & $(50,100$ & $(200,1$ \\
\hline & & 37) & , 40) & 40) & ,40) & , 37) & $0,37)$ & 40) & $00,40)$ \\
\hline Zero & $A$ & 0.7338 & 0.9725 & 0.8994 & 0.9899 & 0.9151 & 0.9811 & 0.8908 & 0.9896 \\
\hline \multirow[t]{2}{*}{ order } & B & 117341 & 12325. & 76830. & 33958. & 156702 & 1112.92 & 142684 & 58208 \\
\hline & & 5 & 14 & 01 & 69 & 6 & & 4 & 3 \\
\hline First & A & 0.7587 & 0.9758 & 0.9125 & 0.9908 & 0.9259 & 0.9829 & 0.9041 & 0.9897 \\
\hline \multirow{2}{*}{ order } & B & 46634. & 106196 & 11532. & 140019 & 109189 & 67661.1 & 105993 & 97122. \\
\hline & & 65 & .1 & 71 & .1 & 5 & 5 & 1 & 1 \\
\hline Higuchi & A & 0.7587 & 0.9758 & 0.9125 & 0.9908 & 0.9259 & 0.9829 & 0.9041 & 0.9897 \\
\hline crowell & B & 1.3687 & 12.267 & 0.9524 & 11.360 & 8.768 & 11.512 & 1.376 & 14.512 \\
\hline Hixon & $A$ & 0.5071 & 0.7580 & 0.5718 & 0.8194 & 0.6217 & 0.8662 & 0.6104 & 0.8836 \\
\hline \multirow[t]{2}{*}{ crowell } & B & 5957.0 & 63.558 & 11.126 & 1725.5 & 6814.3 & 1097.15 & 5783.79 & 1496.2 \\
\hline & & 8 & & & 7 & 5 & & & 3 \\
\hline Korsemeyer & $A$ & 0.7893 & 0.9487 & 0.9487 & 0.9849 & 0.9279 & 0.9535 & 0.9231 & 0.9880 \\
\hline \multirow[t]{2}{*}{ Peppas } & B & 6783.6 & 3047.4 & 17620. & 4300.2 & 9007.2 & 2919.31 & 10611.3 & 2798.2 \\
\hline & & 6 & 8 & 28 & 3 & & & & 2 \\
\hline $\mathrm{N}$ & & 1.2261 & 1.101 & 0.9149 & 1.0269 & 1.1621 & 1.1384 & 1.08 & 1.1392 \\
\hline Exponent & & & & & & & & & \\
\hline
\end{tabular}

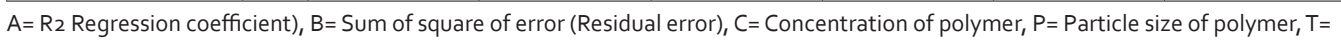

\section{Experiment Matrix Data Analysis, Optimized Solution Generation and Validation}

From the above interpretations from one factor lots like effect of MSM component excipient concentration, temperature, particle size and time of drug release we reached to conclusion that for retarding the release up to $24 \mathrm{hr}$ the MSM component excipient concentration required is on higher size i. e. $200 \mathrm{mg}$ (57.14\%). Temperature and particle size has no impact on drug release so MSM powder with no heat treatment can be considered for dosage form design. Particle size of MSM can be kept 60 mesh for optimized batch solution generation. Time of study could be kept $6 \mathrm{hrs}$ and $12 \mathrm{hrs}$ where expected release range can be considered from 50 to $100 \%$ of drug by entring the value acordingly solutions are generated. Among the generated solutions the solution with $200 \mathrm{mg}(57.14 \%)$ concentration with
MSM Seived through 60 Mesh Seive and with no heat treatment (Room Temperature conditions considered) and time of drug release upto $12 \mathrm{hr}$ was taken out as optimum solution. The probability of drug release is extension upto $24 \mathrm{hr}$ as the release predicted in $12 \mathrm{hr}$ is around 50 to $60 \%$ only. The optimized solution obtained from the model was formulated and the results are performed in the triplicates for determination of $\%$ CDR.

The optimum solution generated showed \% CDR 57.176 \pm 1.253 . Also test for weight variation passed as per I. P. standard. Thickness of tablet was in the range of 3.57-3.62 mm. Hardness of tablet was in the range of $4-4.5 \pm 1.532 \mathrm{~kg} / \mathrm{cm}^{2}$. Percent weight loss in the friability test was found to be less than $0.4 \%$. Content uniformity was found to be within $100 \pm 1 \%$ of the $350 \mathrm{mg}$ of Diclofenac sodium. 


\section{Performance Scale up Trials on Optimized Solutions}

\section{In-vivo bio-waiver using in-vitro simulating conditions (RPM, pH, Temperature)}

From Table 7 it is concluded that all the parameters like change in apparatus, RPM, $\mathrm{pH}$ conditions have impact on the dissolution release profile. In correlation with in-vivo conditions it can be judged that the MSM shows $\mathrm{pH}$ dependent release kinetics. Changes in $\mathrm{pH}$ from stomach, small intestine, large intestine may lead to variation in the release profile of the drug based on the $\mathrm{pH}$ dependent reponse of the excipient component. Moreover changes in release kinetics/release profile based on RPM can also be correlated with changes in release profile in-vivo with respect to changes in the peristaltic movement over the GI tract. Differences in the release profile based on method can be correlated with location of dosage form in body and consumption of acidic or basic food entities may also lead to changes in the release pattern of the dosage form based on changes in the stomach $\mathrm{pH}$. Table 7 Dissolution data profiling-Model independent approach, indicates that all other parameters except Temperature shows impact on the release profiling. Change in the release locations in the body, or changes in gastric motility may have major impact in deciding dosage form performance in terms of functionality and applicability. Decisions on target locations, suitable dosage form modifications can be taken at the development stage itself based on the findings at this step.

\section{Generation of Process Capability Indices}

\section{Process capability index, process performance for set parameters}

From results mentioned in Table 8 considering the release retardant applications of MSM in the concentration range (14.28-57.14\%) prolonging the release from $12 \mathrm{hr}$ to $24 \mathrm{hr}$. The Limits for \% CDR considered in acidic condition for first 2 hrs of release were 25 to $55 \%$ whereas for basic conditions the limits considered

\begin{tabular}{|c|c|c|c|c|}
\multicolumn{5}{|c|}{ Table 7: Dissolution data profiling- Model independent } \\
approach. \\
\hline Dissolution & Dissolution & $\mathbf{5 0 B H 3 7}$ & $\mathbf{1 5 0 B W 3 7}$ & I Profile \\
\hline condition & conditions & F2(A) & F2(B) & (A)(B) \\
\hline code & & & & \\
\hline DI & $50 \mathrm{PH} 37$ & 28.370 & 33.436 & $\begin{array}{c}\text { (Dissimilar)/ } \\
\text { (Dissimilar) }\end{array}$ \\
\hline D2 & $50 \mathrm{BH} 32$ & 76.388 & 17.853 & $\begin{array}{c}\text { (Similar)/ } \\
\text { (Dissimilar) }\end{array}$ \\
\hline D3 & $100 \mathrm{BH} 37$ & 42.916 & 23.940 & $\begin{array}{c}\text { (Dissimilar )/ } \\
\text { (Dissimilar) }\end{array}$ \\
\hline D4 & $50 \mathrm{PW} 37$ & 12.467 & 44.492 & $\begin{array}{c}\text { (Dissimilar )/ } \\
\text { (Dissimilar) }\end{array}$ \\
\hline DS & $50 \mathrm{BW} 32$ & 16.882 & 78.199 & $\begin{array}{c}\text { (Dissimilarj/ } \\
\text { (Similar) }\end{array}$ \\
\hline D6 & $100 \mathrm{BW} 37$ & 23.017 & 47.071 & $\begin{array}{c}\text { (Dissimilar )/ } \\
\text { (Dissimilar) }\end{array}$ \\
\hline D7 & $50 \mathrm{BM} 37$ & 1.499 & 8.197 & $\begin{array}{c}\text { (Dissimilar)/ } \\
\text { (Dissimilar) }\end{array}$ \\
\hline
\end{tabular}

$\mathrm{P}=$ Paddle, $\mathrm{B}=$ Basket, $\mathrm{H}=\mathrm{HCl}(1.2 \mathrm{pH}), \mathrm{W}=\mathrm{PBS}(6.8 \mathrm{pH}), \mathrm{M}+\mathrm{PBS}(8 \mathrm{pH}), 50=50$ $R P M, J O O=J O O R P M, 32=320 \mathrm{C}, 37=370 \mathrm{C}$

\section{Table 8: Process capability index, process performance for set parameters.}

\begin{tabular}{|c|c|c|c|c|c|c|}
\hline \multirow{2}{*}{$\begin{array}{l}\text { Sr. } \\
\text { No. }\end{array}$} & \multirow{2}{*}{ Condition } & \multicolumn{2}{|c|}{ Limit for \% CDR } & \multirow[t]{2}{*}{ Cp } & \multirow{2}{*}{$\begin{array}{c}\text { Cpk } \\
\text { Upper limit }\end{array}$} & \multirow[b]{2}{*}{ Lower limit } \\
\hline & & Upper limit & Lower limit & & & \\
\hline 1 & $\begin{array}{c}\mathrm{P} 0.1 \mathrm{~N} \mathrm{I}-\mathrm{ICl} \\
37,50\end{array}$ & 55 & 25 & 5.560167 & 30.28199 & 35.441805 \\
\hline 2 & B $0.1 \mathrm{~N} \mathrm{HCl} 32,50$ & 55 & 25 & 3.1385 & 28.42917 & 4.465039 \\
\hline 3 & $\begin{array}{c}\text { B } 0.1 \mathrm{NHCl} \\
37,100\end{array}$ & 55 & 25 & 6.748167 & 8.348232 & 5.148101 \\
\hline 4 & $\begin{array}{c}\mathrm{P} 6.8 \mathrm{pH} \\
37,50\end{array}$ & 80 & 45 & 9.424333 & 44.76657 & 40.89171 \\
\hline 5 & $\begin{array}{c}\text { B } 6.8 \mathrm{pH} \\
32,50\end{array}$ & 80 & 45 & 2.849778 & 55.10867 & 2.860091 \\
\hline 6 & $\begin{array}{c}\text { B } 0.1 \mathrm{~N} \mathrm{HCl} \\
37,100\end{array}$ & 80 & 45 & 4.830194 & 2.077444 & 7.582945 \\
\hline
\end{tabular}

Where, $\mathrm{P}=$ paddle, $\mathrm{B}=$ basket, 37 and $32=$ temperature conditions, 50 and $100=\mathrm{RPM}$ conditions 
were 45 to $80 \%$. Variations in RPM and Temperature were also considered simultaneuosly for calculations of process potential and process capability indices. All the values for process potential (Cp) and Process Performance ( $\mathrm{Cpk}$ ) were found to be greater than 2 and greater than 1.33 respectively. The said behaviour indicates that inspite of variable performance of MSM mucilage at acidic and basic conditions but the selected concentration range was well optimized as release retardent dosage form extending the release for about $24 \mathrm{hr}$. The release process performance of the tablet dosage form was found to be highly capable for the selected range of concentration.

\section{CONCLUSION}

The present research work has successfully used Quality by design approach to predict the in-vivo performance of Tablet dosage form based on in-vitro data simulation. One factor design was used with prime focus on impact of Mucuna pruriens seed polymer as excipient on dosage form functionality and applicability. Process flow worksheet was developed. QTPP (Quality target product profile) and CQA (Critical Quality Attributes) data was generated. Risk assessment and Ishikawa diagram (Cause and effect analysis) were found to be helpful to generate the results predicting in vivo performance of dosage from. In terms of applicability, Mucuna Seed mucilage was found to be release retardant excipient in the concentration range 14.28 to $57.14 \%$ (14 to $60 \%$ ) The process capability indices and process potential values were found to be above 2 and 1.33 respectively indicating the release performance in-vivo as per the required specifications of extended or prolonged release dosage form. Predicted variations in release performance based on dissolution data modeling indicated that, the study design could be helpful to analyze the alterations in in-vivo performance based on excipient behavior in simulated conditions tested in-vitro. Any component used as excipient in dosage form could be considered at 'High Risk' as it plays very important role in dosage form performance based on its performance in various in-vivo variations. Maximum possible in-vivo variations under simulated conditions in-vitro should also be considered during product development stage to avoid product failure during exhibit batch trials. It can be concluded that study design with more number of simulating variables could be helpful pattern to come up with exhibit batch performance predictor.

Note: As per revised USP official monograph for Diclofenac Extended release dosage form the dissolution media recommended is $0.05 \mathrm{M}$ phosphate buffer, $\mathrm{pH}$
7.5. ${ }^{16-18}$ But in the present study the aim was to check the release profile and release mechanism of drug with respect to the behavior of new experimental excipient candidate. Moreover the major objective was to check how the in-vivo parameters like dosage form target location, $\mathrm{pH}$, temperature, motility etc play role in deciding the excipients behavior and in turn the performance of dosage form. So the method involved the use of both the acidic and basic $\mathrm{pH}$ conditions to check the dissolution release mechanism and data profiling. Ultimately we could predict the process capability indices and certain conclusions were drawn on the basis of these variables.

Drug was taken as model drug for the said study on novel excipients. The present study target was to justify the behavior of dosage form in relation to the characteristics of new excipients and response of excipients to the in-vivo body conditions. We wanted to study how excipients behavior with respect to body conditions decides the release mechanism and release profiling. In this stage it was not the target to prove the dosage form better in comparison to marketed dosage form. So comparison of release profile with marketed dosage form was not considered.

\section{ACKNOWLEDGEMENT}

- Grateful thanking for all helping hands, Savitribai Phule Pune University Pune, Maharashtra, India

- Special Thanks to Ashwamedh Biotech India Pvt. Ltd., Kopargaon for timely guidance and support.

- Sincere acknowledgements to MET's Institute of Pharmacy, Bhujbal Knowledge City, Adgaon, Nashik for providing necessary facilities for the work.

\section{CONFLICT OF INTEREST}

The authors declare no conflict of interest.

\section{ABBREVIATIONS}

MSM: Mucuna Seed Mucilage; QbD: Quality by design; CQA: Critical Quality Attributes; QTPP: Quality Target Product Profile; Cp: Process potential; Cpk: Process Performance; RPM: Rotations Per Minuite; NDA: New drug Approval Appication.

\section{REFERENCES}

1. Guidance for industry (2009), Q8(R2) Pharmaceutical Development https:// www.fda.gov/downloads/drugs/guidances/ucm073507.pdf (Accessed on 28 December 2017 ) 
2. Example QbD MR Tablet Module 3 Quality, 3.2.P.2 Pharmaceutical Development, December 2011, https://www.fda.gov/media/82834/download (Accessed on 28 December 2017)

3. Example QbD IR Tablet Module 3 Quality 3.2.P.2 Pharmaceutical Development, April 2012 https://www.fda.gov/media/82834/download (Accessed on 28 December 2017)

4. Lampariello LR et al. The Magic Velvet Bean of Mucuna pruriens, J Tradit Complement Med. 2012; 2(4): 331-339. (https://www.ncbi.nlm.nih.gov/pmc/ articles/PMC3942911/?report=printable)

5. Tan NH, Fung SY, Sim SM. Extracts of Cowhage (Mucuna pruriens) Seeds and Anti-Snake Venom Effects, Nuts and Seeds in Health and Disease Prevention 2011: 401-408. https://doi.org/10.1016/B978-0-12-375688-6.10048-9, https:// www.sciencedirect.com/science/article/pii/B9780123756886100489

6. Balangani PK et al. Isolation and charactrization of natural mucilage from leginaria siceraria. International Research Journal of Pharmacy 2014;4(11): 117-121. DOI:10.789/2230-8407.041126 http://www.irjponline.com/admin/ php/uploads/2069_pdf.pdf

7. Farooq U, Malviya R and Sharma PK. Extraction and Characterization of Okra Mucilage as Pharmaceutical Excipient, Academic Journal of Plant Sciences 2013; 6 (4): 168-172, DOI: 10.5829/idosi.ajps.2013.6.4.82292 https://www. idosi.org/ajps/6(4)13/3.pdf

8. Ngwuluka NC et al. Naturapolyceutics: The Science of Utilizing Natura Polymers for Drug Delivery, Polymers 2014; 6: 1312-1332. doi:10.3390/ polym6051312., www.mdpi.com/2073-4360/6/5/1312/pdf

9. Ameena $\mathrm{K}$ et al. Isolation of the mucilages from Hibiscus rosasinensis linn. and Okra (Abelmoschus esculentus linn.) and studies of the binding effects of the mucilages. Asian Pacific Journal of Tropical Medicine 2010; 539-543.
10. Lachman L., Libeberman H. And Kanig J. The theory and practice of industrial pharmacy 1991: 2nd ed. Varghese publishing house, Mumbai, pp. 179-183, 328.

11. Guidance for Industry, 1997, Dissolution Testing of Immediate, Release Solid Oral Dosage Forms, https://www.fda.gov/downloads/drugs/guidances/ ucm070237.pdf) (Accessed on 14 December 2017)

12. Diaz DA et al. Dissolution Similarity Requirements: How Similar or Dissimilar Are the Global Regulatory Expectations? The AAPS Journal 2016; 18(1):16-22. DOI: 10.1208/s12248-015-9830-9, https://www.ncbi.nlm.nih.gov/pmc/articles/ PMC4706290/

13. Hosseinifard SZ and Abbasi B. Process Capability Analysis in Non Normal Linear Regression Profiles, Communications in Statistics - Simulation and Computation 2012;41(10):1761-1784. https://www.tandfonline.com/doi/abs/1 0.1080/03610918.2011.611313

14. Stefen Steiner et al. Understanding Process capability Indices, http://www. stats.uwaterloo.ca/ shsteine/papers/cap.pdf, (Accessed on 12/05/2018)

15. Engineering Statistics Handbook, What is Process Capability, https:// www.itl.nist.gov/div898/handbook/pmc/section1/pmc16.htm (Accessed on 12/05/2018)

16. Diclofenac Sodium delayed release tablet, USP29, http://ftp.uspbpep com/v29240/usp29nf24s0_m24970.html, (Accessed on Accessed on 28 December 2017)

17. Diclofenac Sodium Extended-Release Tablets, USP -NF, Revision Bulletin (01-Mar-2010), https://www.uspnf.com/official-text/accelerated-revisionprocess/accelerated-revision-history/diclofenac-sodium-extended-releasetablets-0, (Accessed on Accessed on 28 December 2017)

18. Diclofenac Sodium Extended-Release Test 1. Tablets, Revision Bulletin (2010), https://www.uspnf.com/sites/default/files/usp_pdf/EN/USPNF/revisions/

\section{SUMMARY}

There is no independent approval process for novel excipients. They are approved as part of an NDA and then only if the drug is approved and only for that particular route of administration and the level of use approved for the NDA. For pharmaceutical companies, it is risky to use a novel excipient because doing so complicates the regulatory issues, because any problem with the new excipient could hold up the approval of the drug product. If the drug fails, the excipient does not receive approval, even if the failure was not related to the excipient and the clinical trial data are not usable, even as a reference."As a result of these combined issues, the regulatory framework for the approval of new excipients creates a dilemma for the manufacturers and users of novel ingredients. Moreover the Novel Excipients Working Group and a similar group formed within IPEC-Americas are currently exploring the development of joint best practices for preclinical safety (testing and specification requirements) and creating a process for designing a well-defined pre-clinical data package for novel excipients. With IPEC-Americas, the group is assessing current challenges to excipient review and approval, and possible next steps to alleviate these challenges.

Considering this dilemma present research work would like to contribute in this process. Formulation development, optimization and validation flow has been proposed on trial basis using Quality by design (QbD) approach. During development stage Critical Quality Attributes (CQA) could be identified based on product parameters and excipient component parameters expected as QTPP (Quality Target product Profile). Critical parameters could be based on both in-vitro and in-vivo product performance expected as QTPP. Accordingly Cause and Effect analysis at two levels could be planned considering both product functionality and simulated invivo excipient performance variables tested in-vitro. This could be considered as Lab Scale Bioequivalence Based on Ishikawa 2, with generation of operating ranges which could be called as, tailored in vitro-in vivo Scaling. If planned appropriately, this would definitely help in generation of scaled batch with reduced chances of failure for in-vivo performance. 


\section{PICTORIAL ABSTRACT}
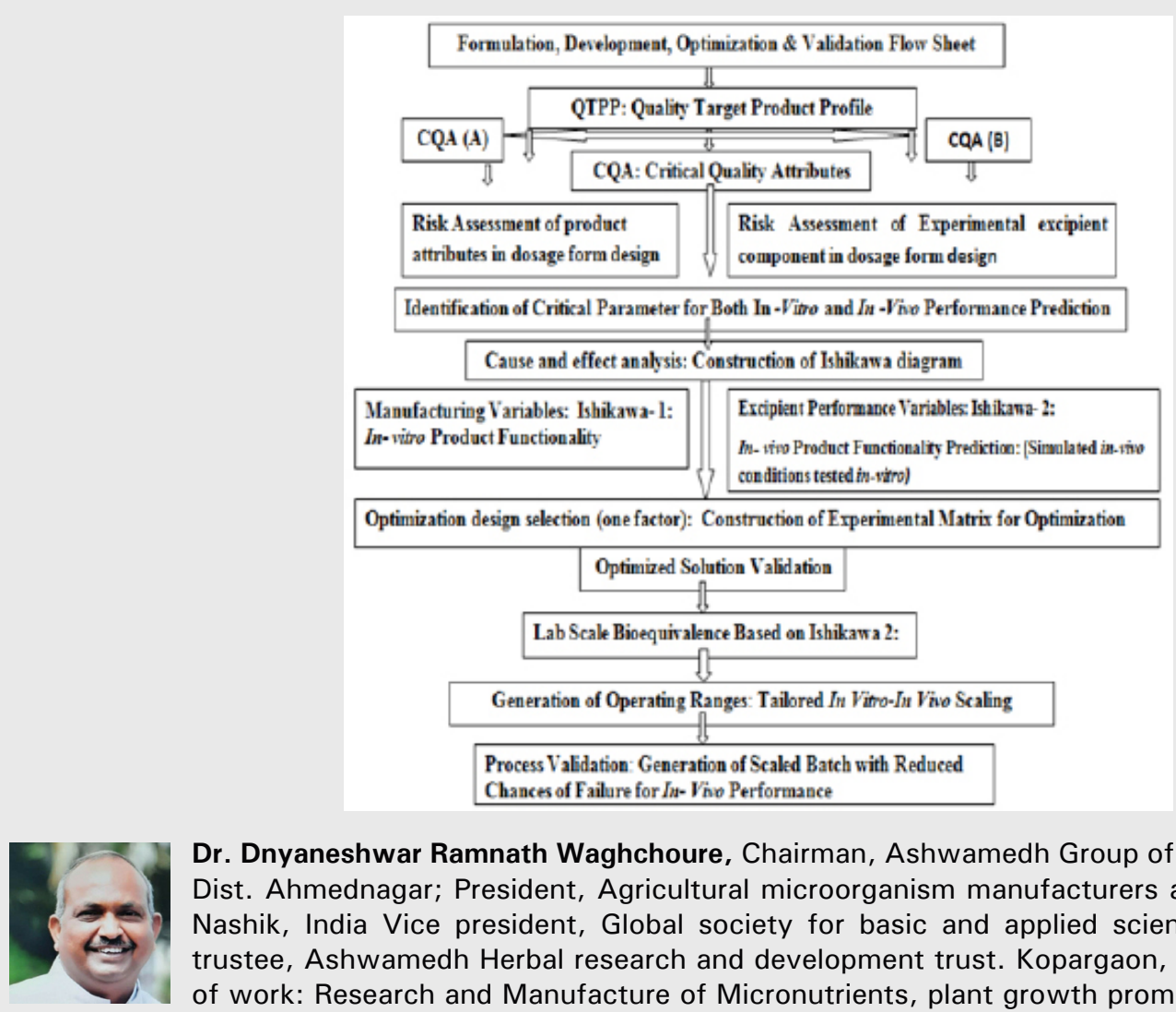

Dr. Dnyaneshwar Ramnath Waghchoure, Chairman, Ashwamedh Group of Industries, Kopargaon, Dist. Ahmednagar; President, Agricultural microorganism manufacturers and farmers association Nashik, India Vice president, Global society for basic and applied sciences Mumbai Executive trustee, Ashwamedh Herbal research and development trust. Kopargaon, Dist. Ahmednagar Area of work: Research and Manufacture of Micronutrients, plant growth promoting products, Organic fertiliser, biocontrol, biopesticides, Ayush Medicine, food products, tea and spices, Agro tourism. Speciality in organic winery input, design and development, Vedic poultry and veterinary products, medicinal plants cultivation, food biotechnology, herbal tea spices and drug design.

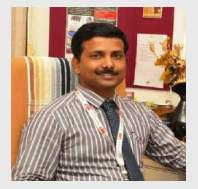

Dr. Sanjay Jayprakash Kshirsagar: He is Principal, MET's Institute of Pharmacy, Bhujbal Knowledge City, Adgaon, Nashik with excellent leadership skills and research attitude. he has research expertise in the area Colon specific drug delivery system, Nanotechnology, $\mathrm{QbD}$ in Formulation development, Transdermal drug delivery system, Liposome targeted drug delivery, Sustained release dosage forms. he is Inspector, Pharmacy Council of India, Savitribai Phule Pune University Duties, Member Board of Studies (BoS) in Pharmaceutics, VC Nominee PhD selection committee.

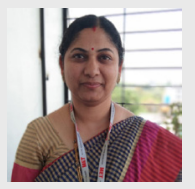

Dr. Gitanjali Sambhajirao Deokar: She has Research Expertise in the area Natural seed polysaccharides and other components as excipients, Functional seed components, Prebiotics and Probiotics- Microbiome balance and Human Health, Analytical method development and validation, Formulation and development, QBD Aaspects, Process validation, scale up studies.

Awards and Achievements: Recipient of Mahakavi Wamandada Kardak Smruti, Adarsh Dnynyogita Award 2009, Pharma Excipient Poster award 2018 (Pharma Excipient International AG, SCHWEIZ). Gold medallist at the university level for post graduate studies. Recipient of SIR Ratan Tata Trust and Suresh Kare - Indoco Foundation scholarships.etc.

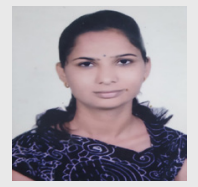

Ms. Harshada Dnyandeo Kakulte, M.Pharm (QAT), Working as Research Scientist at Xylopia Labs Pvt Ltd, Ahmedabad. Author has contributions in the areas like formulation and developments, Analytical method development and Validation, Quality by design. Author has extraordinary learning skills with an objective to explore the novel drug delivery systems.

Cite this article: Deokar GS, Kakulte HD, Kshirsagar SJ, Waghchoure DR. QBD Approach to Predict the in-vivo Performance Based on in-vitro Results using Mucuna pruriens Seed Mucilage as a Novel Tablet Dosage Form Excipient and Dicofenac Sodium as Model drug Candidate. Indian J of Pharmaceutical Education and Research. $2021 ; 55(3): 715-27$. 